\title{
Conceptions of Race Beyond North America: The Subversion of the Colonial Racial Contract in The Bahamas
}

David Allens

In his work Ethnic groups and boundaries, Frederick Barth argues that applying definitions to group of peoples has less to do with emphasizing a shared culture than with defining the sentiments of communality in opposition to the perceived identity of an 'other' (Barth). In applying Barth's framework, modern Bahamian identity has developed-and is largely understood - in comparison to a Haitian 'other.'

Therefore, this essay will argue that, having gone through multiple iterations of the racial contract, policies of subjugation initially intended for black colonial subjects (e.g. uneven development and colonially encouraged distrust) have been subverted for use by The Bahamas' post-independence government against those with Haitian ancestry. It will demonstrate that Bahamian sentiments towards Haitians are contextualized historically and based on a longstanding colonial tradition of discrimination and social control that pitted West Indian immigrants against them. While this subjugation is no longer enforced along phenotypical lines, elements of privilege connected to the racial contract are now adjudicated along different lines that may prove harder to distinguish, perhaps making the privileges attached to the dominant identity different from a North American context.

It is therefore more difficult to define a normative Bahamian while the race of afroHaitians in The Bahamas can easily be described as a group of people bound by the elements of slavery, racism and revolution in Saint-Domingue, political instability in Haiti and the formation of a diasporic group. Regardless, a normative Bahamian will be described below, using Haney Lopez's definition of race as "a vast group of people loosely bound by historically contingent, socially significant elements of their [...] ancestry;" (Lopez).

\section{Historical-Colonial Racial Contract}

Geographically separated from the rest of the West Indies as a part of the isolated island groups of the North American continental shelf (West Indies) and located outside of the Caribbean Sea, Bahamian relations with the rest of the region are complex. As early as 1812, colonial officials commented that Bahamians did not consider themselves West Indians (Saunders 117), nor were they generally accepted as belonging to the region (Lewis).

Historically, The Bahamas was considered one of the least important of an already insignificant group of colonies, and it was once described as "one of the most remote and perhaps poorest parts of the British Empire" (Saunders 2). Compared to the rest of the region, The Bahamas lacks significant natural resources; however, it has still periodically experienced relative prosperity, especially with the growth of tourism in the 1920s. Sparse soil, inconsistent weather patterns across the archipelago, and a lack of valuable deposits (like oil and gold) left the country relegated to an "Atlantic outpost," one incapable of producing large sugar or cotton outputs (Saunders 2). The dynamics resulting from these factors have largely been exploited by British colonialism. 
With the introduction of a multi-racial environment came the need for the legitimization of colonial subjugation through the creation of a racial contract. After decades of migration, white Europeans had begun assimilating into the Bahamian environment. becoming less normatively 'white'. By aligning themselves with the general colonial archetype, most British settlers and officials held the racial prejudices of Bahamian whites and saw non-whites as "childlike, dependent, [and] irresponsible loafers in the sun"(Kiernan 201). Charles Mills argues that a racial contract requires its signatories to subscribe to misunderstandings about the world under the assurance that these conceptions will be validated by a universal "white epistemic authority." According to Mills, unlike an ideal social contract, these prescribed misunderstandings-or "localized and global cognitive dysfunctions"-require their own prescribed "schedule of structural blindness and opacities" to maintain white supremacist order (Mills 18). An argument may be made that the perpetuation of these ideas is represented in policies and socially-accepted practices ranging from apprenticeship, customary residential segregation and formalized public segregation to cater to tourists from the U.S. South during prohibition (Brereton).

With the racial contract, a "color-coded morality" exists that creates a single, fixed consciousness that restricts equality to the dominant identity. This fixed state consciousness is a departure from the fluid one needed to create a universal identity. However, race dynamics do not necessarily remain fixed on an exclusively black-white framework with 'whites' existing as the only dominant identity. The archetype of a 'Bahamian' generally exists as a response to "incursions of immigrants from the rest of the British Caribbean (attracted by the relative prosperity of The Bahamas) and from Haiti" (Johnson 13-20). It may be further argued that the "animus against West Indians was the continuation of a long-established tradition"(Johnson). For example, with the 1891 Police Act, the Bahamian colonial office created a new police force (phasing out the Bahamian comprised force) that included among its numbers members from West Indian colonies "to prevent any feelings of local sympathy between [the] police and the inhabitants of The Bahamas" (Themistocleous 172 ). Compared to the now defunct force, new recruits were described as "literate, as might be expected of the superior class of which they [were] drawn"(Tinker 39). As has been demonstrated in other works, this colonialist practice of using blacks to infiltrate and keep other blacks down is incredibly damaging (Fanon).

Similarly, despite a previously mutual migration pattern, animosity towards Haitians began following the start of the Haitian revolution, when the presence of a large number of nonwhite immigrants created discontent and fear among white residents (Tinker 98). By the time Saint-Domingue achieved independence from France in 1804, migration had almost ceased. Bahamian planters were not only concerned with competition from white French immigrants but "like all whites[, they were] terrified by the prospect of the spread of a Haitian-type slave revolt"(Craton 267). This discontent increased when The Bahamas became more economically prosperous at the same time that the Haitian economy plummeted under the Duvalier dictatorships (D'Agostino 122). This led to colonial officials initiating restrictive policies against Haitians.

\section{Modern Racial Contract}

Despite the internalized colonial mentality, all of the traditional demarcations that ranked cultural-ethnic and racial groups did not remain. Based on latest census data, the Bahamian population has maintained a majority black population. As of $2010,90.6 \%$ of the population is 
black, $4.7 \%$ white, $2.1 \%$ black and white, and the remainder $(2.6 \%)$ either identifying as other or unspecified (Central America: Bahamas). Many of the other West Indian immigrants who immigrated and established affluent positions integrated with the Bahamian middle class.

This dichotomy is due in large part to a growth in prosperity and the achievement of political change without instability beginning in the 1950s (and again around the 1970s),. The political change that led to independence also led to policies like "Bahamianization," which aimed to ensure that the economic and social benefits of The Bahamas were in the hands of normative 'Bahamians' (Tinker 147). However, those charged with this political change largely included those assimilated West Indian immigrants whose linage included prominent, lawyers, businesspersons, medical and academic doctors, and politicians (Tinker 47) (including the country's first premier and prime minister, the son of a Jamaican policeman). At the same time, Haiti inexorably moved towards becoming one of the poorest, most heavily populated nations under an oppressive and corrupt regime (Craton 268). So while the normative 'Bahamian' was loosely demarcated at best, it firmly included the black elite and excluded what was now seen as the black poor.

In The Bahamas, afro-Haitians are often relegated to menial jobs, poverty and discrimination from various sectors of society (Belton 949). Jodi Melamed posits that this is systemic of racial capitalism (76). It is generally accepted that Bahamians do not want the menial jobs carried out by Haitians. Therefore, the ability to rely on other means of employment and the development of The Bahamas rely on relations of severe inequality between afro- Bahamians and Haitians. Much like Melamed, Mills argues that economic disparities form the foreground of power dynamics with a moral hierarchy and juridical partitioning existing to justify exploitation and privilege (Mills). As a result, stereotypes that depict Haitians as the 'other' persist today. It is common in the everyday discourse among Bahamians to hear Haitians described with undesirable and negative connotations. In conversation with young Bahamian school children, one writer recalls stating his Haitian heritage, to which he received both surprise and statements like they "smell bad" and "look like rat[s]" (Bertin) in response. These statements highlight how definitions of race take abstract categorizations to create an illusion that does the ideological work of marginalizing communities instead of maintaining objective biological facts (McCarthy 5).

The surprise at the writer's Haitian heritage is notable. It reveals that Bahamians do not know what makes a 'Haitian a Haitian' nor does it matter. There is now just a socio-historical structural need for an upwardly mobile population to have another class to contrast itself with, on that it regards and treats as inferior in status and culture. For socio-cultural reasons, Haitians happen to be that necessary replacement.

While stated earlier that defining the normative Bahamian may prove challenging, this essay will still do so here to emphasize why Haitian presence proves so challenging and why this colonial demarcation may have remained. Bahamians are anglophone small islanders that have been ethnically and socially creolized, and shaped by a shared environment and common history (Craton 284). Historically, unlike Haitians, Bahamians have not had to resort to overly violent means to achieve political success, instead having come by independence peacefully. Even in the era of slavery, due to the lack of large sugar and cotton plantations, Bahamian slaves were treated relatively well (Bahamians Have a Slave Mentality). This intrinsic need for violence to secure peace is thus not inculcated in Bahamian culture. In contrast, Haitians are largely proud of 
their heritage, a fact that is exploited by Bahamians to reinforce the stereotype that Haitians are "violent migrants from a country that seemingly cannot rule itself" and who present "the potential to destroy The Bahamas" (Bertin). In short, Haitians are viewed as "more African, unmodernized, superstitious, fatalistic, emotional and at least potentially violent" (Craton, 284). This view manifest itself so often that there exists a myth that Bahamians descend from a different tribe of Africans who were more docile in nature than Haitians, who come from a more bellicose lineage.

The description of "more African, unmodernized" (Craton) and the increased likelihood of experiencing poverty(Belton) is significant. Firstly, through initial hierarchies established in the colonial racial contract, or the spectrum of Whiteness vs. Blackness, situates a greater proximity to Africanness near the lower strata of society. Secondly, in the same way that illegality has been associated with Mexicans in the United States, illegality, immigration, poor education, poverty, and overpopulation have been associated with Haitians in the Bahamas. The political and socioeconomic problems of Haiti have been cited as proof of this characterization. Not only are the conditions in Haiti portrayed as undesirable, those who flee those conditions to immigrate to The Bahamas (mostly irregularly) leave to live in comparably undesirable conditions "with the presence of discarded human usage, waste, combined with the presence of domestic livestock" (Shanty Town Residents Fear Crackdown). This creates an environment where afro-Haitians are associated with these characteristics regardless of their actual immigration/citizenship or economic status.

This can be seen as a translation of the already existing racial contract to one that utilizes 'Whiteness. If one understands Whiteness not as a color but as a set of power relations (Mills 127), then the treatment of Haitians in The Bahamas can be seen as adherence to this dynamic. The implicit contract is now instead with the ruling, socially-constructed afro-Bahamian class against that of the minority afro-Haitian. Placing Haitians as less modern and more African confers more privilege to the dominant group in the already established colonial hierarchy. As Taayab Mahmud argues, this perceived hierarchy brings with it an ideal of the responsibility of modernity and a duty to govern with reason and rule of law (Mahmud 53). Ignoring policies against Haitians initiated by colonial officials, post-independence, successive majority afroBahamian governments have "attempted to curb illegal migration through the use of systematic raids, arrests, and mass deportations" (Tinker 122). These efforts have taken numerous forms including a work permit program that a Yale Human Rights Delegation Report argued resembled indentured servitude (Bertin 82), and the passage of the 1973 Nationality Act that changed citizenship to jus sanguinis (Perry). Further, a review of media reports about Haitian nationals by the University of The Bahamas found that the media portrayed the migrant population "in a way that heighten[ed] the public's perceived threat" and increased the perception of the population "to anywhere from 25,000 to 95,000 plus Haitians in a country of only 300,000 plus" (Bertin 85).

Much like the racialization of the Mexican population of the United States described by Haney Lopez, these factors can be seen as part of the racial fabrication of the afro-Haitian population. In the early 1800s, Latin American nationality was separate from race; however, as 'U.S. Anglos' looked at Mexicans with increased animus in the 1840s and 50s, their race and nationality began to be conflated (Haney-Lopez). Similarly, as animosity brewed, Haitian nationality and race/ethnicity were connected; however, without obvious phenotypical distinctions, the unearned advantage and conferred dominance of privilege becomes harder to adhere to. Unlike race, ethnic markers are not ascriptive in the same ways and are not always 
immediately apparent like 'biological' differentiation. Walton argues that despite it being integral to an individual's personhood, ethnicity is "not built on specific, permanent cultural traits but rather constructed and changed over time as a result of interactions with different groups and individuals" (Walton 4). Therefore, an argument may be made that relying on socially defined metrics that are stand-ins for ethnicity-like anglophone names, perceived education level, and accents - makes the "intellectually convenient, [and] cognitively ingrained" process of ignoring diverse voices easier (Harris).

However, the intrinsic permeability of ethnicity easily allows transitions back and forth between identities under the right circumstances. Thus, a deeper analysis of how privilege is granted to the dominant ideology is required.

This essay has sought to describe how a historical colonial racial contract that subjected a majority afro-Bahamian population transformed into a racial contract predicated on Whiteness, where a majority afro-Bahamian government and society still holds the same anti-black sentiments over their afro-Haitian population. However, more consideration is needed for the adaptation of the racial contract for areas where phenotype and general physicality are similar. At the same time, one may argue that, under this racial contract, privilege as a dominant identity is doled out arbitrarily and without concern for an individual's legitimate ethnic distinctions. It is merely the substitute for inferiority in any situation. 


\section{Works Cited}

Barth, Fredrik. Ethnic Groups and Boundaries: The Social Organization of Culture Difference. Little, Brown and Co., 1969.

Belton, Kristy A. "Dry Land Drowning or Rip Current Survival? Haitians without Status in the Bahamas." Ethnic and Racial Studies, vol. 34, no. 6, 2011, pp. 948-66. Scholars Portal Journals, doi:10.1080/01419870.2010.526236.

Bertin, Louis. "The Haitian Diaspora in the Bahamas: An Alternative View." Wadabagei: A Journal of the Caribbean and Its Diasporas, vol. 13, no. 3, Fall 2011, pp. 74-94.

Central America :: Bahamas, The - The World Factbook - Central Intelligence Agency. https://www.cia.gov/library/publications/the-world-factbook/geos/bf.html. Accessed 29 Sept. 2019.

Craton, Michael. "The Bahamian Self and the Haitian Other: The Migration of Haitians to and through the Bahamas, 1950-2000." Immigrants \& Minorities, vol. 14, no. 3, 1995, pp. 265-88. Scholars Portal Journals, doi:10.1080/02619288.1995.9974867.

D'Agostino, Thomas J. "Caribbean Politics." Understanding the Contemporary Caribbean, 2nd ed., Ian Randle Publishers, 2009, pp. 87-131.

Fanon, Frantz. Black Skin, White Masks. Grove Press, 2008.

Guardian, The Nassau. "Bahamians Have a Slave Mentality." The Nassau Guardian, 20 July 2011, https://thenassauguardian.com/2011/07/20/bahamians-have-a-slave-mentality/.

--- "Shanty Town Residents Fear Crackdown.” The Nassau Guardian, 15 May 2013, https://thenassauguardian.com/2013/05/15/shanty-town-residents-fear-crackdown/.

Haney-Lopez, Ian F. "The Social Construction of Race.” Critical Race Theory: The Cutting Edge, Temple University Press, 2013. ProQuest Ebook Central, http://ebookcentral.proquest.com/lib/utoronto/detail.action?docID=1210896.

Harris, Angela P. "Race and Essentialism in Feminist Legal Theory." Critical Race Theory: The Cutting Edge, Temple University Press, 2013. ProQuest Ebook Central, http://ebookcentral.proquest.com/lib/utoronto/detail.action?docID=1210896.

Johnson, H. "National Identity and Bahamian Culture." Yinna: Journal of the Bahamas Association for Cultural Studies, vol. 1, 2000, pp. 13-20.

Lewis, Gordon K. The Growth of the Modern West Indies. Ian Randle Publishers, 2004.

Mahmud, Taayab. "Colonialism and Modern Constructions of Race: A Preliminary Inquiry." University of Miami Law Review, vol. 53, July 1999, https://getit.library.utoronto.ca/index.php/oneclick?ctx_ver=Z39.88-

2004\&ctx_enc=info\%3Aofi\%2Fenc\%3AUTF-

8\&rfr_id=info\%3Asid\%2Fsummon.serialssolutions.com\&rft_val_fmt=info\%3Aofi\%2Ff $\mathrm{mt} \% 3 \mathrm{Akev} \% 3 \mathrm{Amtx} \% 3 \mathrm{Ajournal} \& \mathrm{rft}$. genre=article \&rft.atitle=Colonialism+and+modern + 
constructions+of +race\%3A+a+preliminary+inquiry\&rft.jtitle=University+of+Miami+La $\mathrm{w}+$ Review\&rft.au=Mahmud\%2C+Tayyab\&rft.date=1999-07-

$01 \&$ rft.pub=University+of+Miami\&rft.issn $=0041-$

9818\&rft.volume $=53 \& r f t$.issue $=4 \&$ rft. spage $=1219 \&$ rft.externalDBID=BSHEE\&rft.exter nalDocID=A58919158.

McCarthy, Cameron. "The Theoretical Status of the Concept of Race." Race, Identity, and Representation in Education, Routledge, 2005, https://books-scholarsportalinfo.myaccess.library.utoronto.ca/en/read?id=/ebooks/ebooks4/taylorandfrancis4/201806-06/10/9781136764486\#page=32.

Melamed, Jodi. "Racial Capitalism." Critical Ethnic Studies, vol. 1, no. 1, 2015, pp. 76-85. JSTOR, doi:10.5749/jcritethnstud.1.1.0076.

Mills, Charles W. Racial Contract. Cornell University Press, 1999. ProQuest Ebook Central, http://ebookcentral.proquest.com/lib/utoronto/detail.action?docID=3138625.

Perry, Charmane M. "It's Better in the Bahamas" the Stigma of Being Haitian, Citizenship and Identity Choices Among Second-Generation Haitians in the Bahamas. 2017.

Saunders, Gail. Race and Class in The Colonial Bahamas, 1880-1960. University Press of Florida, 2016.

Tinker, Keith L. The Migration of Peoples from the Caribbean to the Bahamas. University Press of Florida, 2011.

Walton, Matthew J. 'The 'Wages of Burman-Ness:' Ethnicity and Burman Privilege in Contemporary Myanmar.” Journal of Contemporary Asia, vol. 43, no. 1, 2013, pp. 1-27. Scholars Portal Journals, doi:10.1080/00472336.2012.730892.

“West Indies: Encyclopaedia Britannica.” Encyclopaedia Britannica, Dec. 2018, https://www.britannica.com/place/West-Indies-island-group-Atlantic-Ocean. 